\section{Home Hospitalization (HH): An Alternative for the Initiation and Control of Mechanical Non- Invasive Ventilation (NIV)}

\section{Rosalía Doménech-Clar ${ }^{1 *}$, Luís Compte-Torrero², Elisa Soriano- Melchor $^{1}$, Montserrat León-Fábregas ${ }^{2}$, Vicente Ruiz-García ${ }^{1}$ and Bernardo Valdivieso-Martínez ${ }^{1}$}

${ }^{1}$ Unidad de Hospitalización a Domicilio, Hospital Universitari i Politecnic La Fe, Avenida Abril Martorell, Valencia, Spain

${ }^{2}$ Servicio de Neumología del Hospital Universitari i Politècnic La Fe, Valencia, Spain

\begin{abstract}
Introduction and objective: In view of the large number of patients undergoing long-term NIV, there is a need for alternatives to conventional hospitalization. Our goal has been to prove that $\mathrm{HH}$ is at least as efficient as conventional Hospitalization

Method: This is aretrospective cohort study, based on the analysis of results obtained with $\mathrm{HH}$ by one respiratory medicine team between 2004 and 2019. The patients were adapted to ventilation and monitored both at home and at out-patient visits, before ultimately receiving palliative care at home.
\end{abstract}

Results: 251 patients were followed up in $\mathrm{HH}$; of these, 106 had a diagnosis of Amyotrophic Lateral Sclerosis (ALS). A further 350 patients were followed up in Conventional Hospitalization $(\mathrm{CH})$; of these, 141 had ALS.

Among the ALS patients, $4.5 \%$ of those fromHH group were admitted to hospital due to an exacerbation, as opposed to $13.8 \%$ of those from $\mathrm{CH}$. Among the remaining patients, $7.4 \%$ from $\mathrm{HH}$, as opposed to $14.5 \%$ from $\mathrm{CH}$ group.

Of the ALS patients, 152 died; of these, 73 came from $\mathrm{HH}$ group, where the mean survival was 26.38 (27.72) months. In $\mathrm{CH}, 79$ ALS

*Corresponding author: Rosalía Doménech-Clar, Unidad de Hospitalización a Domicilio, Hospital Universitari i Politecnic La Fe, Avenida Abril Martorell Valencia, Spain, Tel: +34687514000; E-mail: rosaliadom21@gmail.com

Citation: Doménech-Clar R, Compte-Torrero L, Soriano-Melchor E, RuizGarcía V, Valdivieso- Martínínez B, et al. (2020) Home Hospitalization $(\mathrm{HH})$ An Alternative for the Initiation and Control of Mechanical Non-Invasive Ventilation (NIV). J Pulm Med Respir Res 6: 043.

Received: October 06, 2020; Accepted: October 20, 2020; Published: October 27,2020

Copyright: (C) 2020 Doménech-Clar R, et al. This is an open-access article distributed under the terms of the Creative Commons Attribution License, which permits unrestricted use, distribution, and reproduction in any medium, provided the original author and source are credited. patients died, with a mean survival of 14.64 (16.54) months ( $p=0.02)$.

Significant differences $(p=0.01)$ were found in patients with thoracic disease, but this was not the case in those with neuromuscular disease $(p=0.989)$.

In $\mathrm{HH}$ group, $74 \%$ of the ALS patients and $71 \%$ of the non-ALS patients died at home, whereas $32 \%$ of the ALS patients and $23 \%$ of the non-ALS patients $\mathrm{CH}$.

Conclusion: $\mathrm{HH}$ represents a good alternative to conventional hospitalization.

Keywords: Chronic patients; Home hospitalization units; Mechanical ventilation; Survival

\section{Introductionand Objective}

Mechanical Non-Invasive Ventilation (NIV) has proved effective in treating hypercapnic respiratory insufficiency, as it improves sleep structure and the exchange of arterial gases, while reducing the number of hospital admissions for exacerbation and thus enhancing the quality of life $[1,2]$.

NIV is the treatment of choice in respiratory care for neuromuscular patients, as well as those with thoracic cage disorders associated with restricted ventilation [3]; it has also proved effective against other diseases like COPD and the Obesity Hypoventilation Syndrome (OHS) [4,5].

The number of patients treated with NIV has increased exponentially in recent years. Back in 2005 the multi-centre Eurovent [6] study was already indicating a mean prevalence of 6.6 ventilated patients per 100,000 people. Greater life expectancy and an accompanying upsurge in complex diseases has led to an abundance of long-term users of NIV. This longevity brings undoubted benefits to society, but it also entails considerable healthcare expenses [7].

Consequently, there is a need to find alternatives to conventional hospitalization, but most NIV teams adapt their patients to ventilation and follow them up in a conventional manner, with only a very few taking advantage of other resources like day hospitals [8], telemonitoring [9] and Home Hospitalization (HH) [2].

Telemonitoring [9] and $\mathrm{HH}$ [10] can be useful care formats for many patients if teams are appropriately trained for the purpose. $\mathrm{HH}$ has been shown to present the same efficacy as conventional hospitalization (or even more so), and there is evidence that is more cost-effective [11,12], as well as achieving good results and improved comfort in the follow-up of patients with complex diseases $[13,14]$.

Our goal has been to analyze and describe the results obtained in a $\mathrm{HH}$ mechanical ventilation programme undertaken by in the $\mathrm{HH}$ unit of a reference acute care hospital; and to prove that $\mathrm{HH}$ is at least as effective as Conventional Hospitalization $(\mathrm{CH})$. 
Citation: Doménech-Clar R, Compte-Torrero L, Soriano-Melchor E, Ruiz-García V, Valdivieso- Martínínez B, et al. (2020) Home Hospitalization (HH): An Alternative for the Initiation and Control of Mechanical Non-Invasive Ventilation (NIV). J Pulm Med Respir Res 6: 043.

- Page 2 of 6 •

\section{Patients and Methods}

This is aretrospective cohort study, based on the results obtained with $\mathrm{HH}$ by a respiratory medicine team.A respiratory medicine team with experience in $\mathrm{HH}$ mechanical ventilation was created in our hospital in 2003. It comprised one doctor (a specialist in respiratory medicine) and two nurses, as well as an administrative nurse who undertook telephone monitoring. The team could also draw on the services of a psychologist, a physiotherapist and a social worker who belong to the hospital staff. Patients have at their disposal a phone number to contact every day of the week from 8AM to 10PM.

Since then, patients with restrictive ventilatory disorders indicated for the application of Mechanical Ventilation (MV), according to the criteria of the BTS [15], were adapted to it in their home, if this was situated within the geographical area covered by $\mathrm{HH}$; if their home fell outside this area, they were adapted in the hospital via a conventional admission. Both geographical areas belong to the same region and share similar socio-economic characteristics.

The adaptation followed the same protocol in both groups: Daytime ventilation in the first 48 hours, with the introduction of nighttime ventilation on the third day. We monitored the procedure's effectiveness by means of arterial gasometry, nighttime pulsioximetry and analysis of the ventilator's curve readings.

All the patients were subsequently followed up at outpatient respiratory medicine visits. As the disease progressed, the $\mathrm{HH}$ patients were also monitored at home, in visits that alternated with their outpatient appointments, before eventually continuing with palliative home care. In this group, patients can contact by phone in cases of exacerbation to be visited at home (pulmonologist and nurse), avoiding conventional hospitalization, provided that it is not a severe decompensation. Any decompensation of patients followed in $\mathrm{HC}$ is handled at the hospital, via a conventional admission, and at the end of the disease they are also admitted to the hospital to be able to provide them with palliative care.

The results were analyzed with SPSS 17.0 and Excel 2010. In the comparisons made with the Student $T$ test, we considered $\mathrm{p}<0.05$ as a statistically significant difference.

\section{Results}

Between January 2004 and June 2019 we attended 601 patients: 310 men with a mean age of 56.5 (SD: 17.3) years and 291 women with a mean age of 66.2 (SD: 16.1) years. The age, gender and diagnosis of the patients followed up in HHand in a conventional hospital -are presented in tables $1 \& 2$.

We used the Student $\mathrm{T}$ test to evaluate any differences in lung function and gaseous exchange in the two groups at the start of the follow-up, with ALS patients separated from the rest (Tables $3 \&$ 4). The only significant difference was in the $\mathrm{PaO} 2$ of the non-ALS patients, which was higher in the conventional hospitalization group.

With respect to the patients who died, we evaluated their admissions to a conventional hospital ward over the course of their follow-up. Among the ALS patients, $4.5 \%$ of those in group $\mathrm{HH}$ were admitted to hospital, as opposed to $13.8 \%$ of those in $\mathrm{CH}$ group. Among the other patients, $7.4 \%$ fromHHgroup were admitted to hospital, as opposed to $14.5 \%$ from $\mathrm{CH}$.

\begin{tabular}{|c|c|c|c|}
\hline & $\mathbf{1 1 1}$ male patients & $\mathbf{1 4 0}$ female patients & Total \\
\hline Age: Mean (standard deviation) & $62.1(14.9)$ years & $70.1(13.5)$ years & \\
\hline ALS & 50 & 56 & 106 \\
\hline Duchenne dystrophy & 6 & & 6 \\
\hline Neuromuscular Disease (NMD) & 29 & 26 & 55 \\
\hline Medullary Lesion (ML) & 5 & 5 & 10 \\
\hline Diaphragmatic Relaxation (DR) & 1 & 8 & 9 \\
\hline Obesity Hypoventilation (OHS) & 2 & 19 & 21 \\
\hline Thoracic cage Disorders (TD) & 17 & 27 & 44 \\
\hline Others & 1 & 3 & 4 \\
\hline
\end{tabular}

Table 1: 251 patients followed in HH. Distribution by gender and diagnosis.

\begin{tabular}{|c|c|c|c|}
\hline & 199 male patients & 151 female patients & Total \\
\hline Age: Mean (standard deviation) & $53.4(17.7)$ years & $62.6(17.5)$ years & \\
\hline ALS & 79 & 62 & 141 \\
\hline Duchenne dystrophy & 22 & & 22 \\
\hline Neuromuscular Disease (NMD) & 54 & 37 & 91 \\
\hline Medullary Lesion (ML) & 6 & 4 & 10 \\
\hline Diaphragmatic Relaxation (DR) & 1 & 5 & 6 \\
\hline Obesity Hypoventilation (OHS) & 9 & 20 & 29 \\
\hline Thoracic cage Disorders (TD) & 22 & 1 & 23 \\
\hline Others & 6 & 1 & 7 \\
\hline
\end{tabular}

Table 2: 350 patients followed up in CH. Distribution by gender and diagnosis.

\begin{tabular}{|c|c|c|c|}
\hline & Hospital at home (HH) & $\begin{array}{c}\text { Conventional Hospitalization } \\
\text { (CH ) }\end{array}$ & p \\
\hline $\mathrm{PaO} 2(\mathrm{mmHg})$ & $69.66(15.07)$ & $76.72(14.14)$ & 0.54 \\
\hline $\mathrm{PaCO} 2(\mathrm{mmHg})$ & $47.21(7.67)$ & $45.91(11.54)$ & 0.64 \\
\hline $\mathrm{pH}$ & $7.39(0.03)$ & $7.40(0.04)$ & 0.28 \\
\hline $\mathrm{FVC}(\mathrm{L})$ & $2.21(0.87)$ & $2.60(1.22)$ & 0.25 \\
\hline $\mathrm{FVC} \%$ & $70.31(27.34)$ & $76.93(26.97)$ & 0.18 \\
\hline FEV1(L) & $1.73(0.72)$ & $3.21(8.90)$ & 0.44 \\
\hline FEV1\% & $68.33(26.01)$ & $74.77(42.34)$ & 0.39 \\
\hline FEV1/FVC\% & $78.69(11.89)$ & $75.63(10.47)$ & 0.11 \\
\hline TLC (L) & $3.9(1.09)$ & $5.74(11.54)$ & 0.77 \\
\hline TLC\% & $74.89(20.47)$ & $77.33(20.86)$ & 0.74 \\
\hline PIM cmH2O & $48.28(15.57)$ & $56.96(26.08)$ & 0.20 \\
\hline PEM cmH2O & $68.77(27.68)$ & $82.11(39.48)$ & 0.42 \\
\hline \multicolumn{2}{|c|}{ Table 3: Lung function and arterial gasometry in ALS patients. } \\
\hline
\end{tabular}

An analysis of the last 5 years shows that the means of annual hospital admissions from $\mathrm{HH}$ were 27 patients for adaptation to ventilation and 15.8 for exacerbation; of these, $3.2 \%$ had to be admitted because of a lack of control at home or their desire to be an organ donor.

In this period, the mean of annual home visits was 104.6 doctor's visits and 118.6 visits by nursing staff for routine controls.

With respect to the home hospitalizations for adaptation to the ventilation, the patients received a mean of 4.3 doctor's visits and 3.5 nursing visits, whereas those for exacerbation incurred a mean of 3.4 doctor's visits and a mean of 5.2 nursing visits. 
Citation: Doménech-Clar R, Compte-Torrero L, Soriano-Melchor E, Ruiz-García V, Valdivieso- Martínínez B, et al. (2020) Home Hospitalization (HH): An Alternative for the Initiation and Control of Mechanical Non-Invasive Ventilation (NIV). J Pulm Med Respir Res 6: 043.

- Page 3 of 6 •

\begin{tabular}{|c|c|c|c|}
\hline & $\begin{array}{c}\text { Hospital at home } \\
\text { (HH) }\end{array}$ & $\begin{array}{c}\text { Conventional hospitalization } \\
\text { (CH ) }\end{array}$ & $\mathbf{p}$ \\
\hline $\mathrm{PaO2}(\mathrm{mmHg})$ & $66.23(15.35)$ & $72.53(17.41)$ & 0.02 \\
\hline $\begin{array}{c}\mathrm{PaCO} 2 \\
(\mathrm{mmHg})\end{array}$ & $48.91(11.30)$ & $48.99(11.16)$ & 0.45 \\
\hline $\mathrm{pH}$ & $7.38(0.79)$ & $7.39(0.04)$ & 0.32 \\
\hline $\mathrm{FVC}(\mathrm{L})$ & $2.01(1.04)$ & $1.97(1.02)$ & 0.17 \\
\hline $\mathrm{FVC} \%$ & $60.82(45.7)$ & $58.74(27.29)$ & 0.18 \\
\hline $\mathrm{FEV1} 1 \mathrm{~L})$ & $1.49(0.88)$ & $1.56(0.85)$ & 0.3 \\
\hline $\mathrm{FEV} 1 \%$ & $59.01(52.5)$ & $55.05(25.13)$ & 0.12 \\
\hline FEV1/FVC\% & $76.6(15.03)$ & $77.942(13.02)$ & 0.15 \\
\hline $\mathrm{TLC}(\mathrm{L})$ & $3.284(1.7)$ & $3.98(4.23)$ & 0.69 \\
\hline $\mathrm{TLC} \%$ & $62.76(24.98)$ & $64.58(23.19)$ & 0.36 \\
\hline PIM cmH2O & $49.92(21.95)$ & $53.2(25.67)$ & 0.19 \\
\hline PEM cmH2O & $72.23(36.31)$ & $68.63(37.04)$ & 0.72 \\
\hline
\end{tabular}

Table 4: Lung function and arterial gasometry in non-ALS patients (male and female).

Thirty-nine patients refused to keep using NIV, abandoning the treatment: 9 from $\mathrm{HH}$ group( 2 of them ALS patients) and 30 from $\mathrm{CH}$ group (5 of them ALS patients).

A total of 152 ALS patients died over the course of these 15 years; of these, 73, with a mean age of 68.8 (10.3) years, belonged to $\mathrm{HH}$ group, with a mean survival of 26.38 (27.72) months (median: 17 months). In -CH group, 79 patients died, with a mean age of 63.6 (10.9) years, with a mean survival of 14.64 (16.54) months (median: 11 months $)$. We found statistically significant differences $(\mathrm{p}=0.02)$ between the survival rates of the two groups.

As regards deaths from other causes, these are shown in table 5. We used the Student $T$ test to evaluate two samples of patients with thoracic disease and we found statistically significant differences between the survival rates of the two groups $(p=0,01)$, but this was not the case with those with neuromuscular disease $(p=0.989)$. The other diagnoses were not analyzed, on account of the small number of patients involved.

\begin{tabular}{|c|c|c|c|c|c|c|}
\hline \multirow[b]{2}{*}{ Diagnosis } & \multicolumn{2}{|c|}{$\begin{array}{c}\text { No. of } \\
\text { patients }\end{array}$} & \multicolumn{2}{|c|}{ Age in years } & \multicolumn{2}{|c|}{ Survival in months } \\
\hline & $\mathrm{HH}$ & $\mathrm{CH}$ & $\mathrm{HH}$ & $\mathrm{CH}$ & $\mathrm{HH}$ & $\mathrm{CH}$ \\
\hline ALS & 73 & 79 & $68.8(10.3)$ & $63.6(10.9)$ & $\begin{array}{c}26.38(27.72) \\
\text { median: } 17\end{array}$ & $\begin{array}{c}14.64(16.54) \\
\text { median: } 11\end{array}$ \\
\hline Duchenne & 5 & 4 & $28.8(4)$ & $36(5.8)$ & $\begin{array}{l}94.2(41.52) \\
\text { median: } 105\end{array}$ & $\begin{array}{c}161(20.9) . \\
\text { median:162.5 }\end{array}$ \\
\hline NMD & 19 & 18 & $66.5(12.1)$ & $56.1(17.1)$ & $\begin{array}{l}68.63(65.6) \\
\text { median: } 39\end{array}$ & $\begin{array}{l}68.61(50.91) \\
\text { median: } 64.5\end{array}$ \\
\hline $\begin{array}{l}\text { Medul- } \\
\operatorname{lar} \mathrm{L}\end{array}$ & 2 & 2 & $66(7.1)$ & $53(18.4)$ & $\begin{array}{l}125(14.14) \\
\text { median: } 125\end{array}$ & $\begin{array}{c}13.5(10.6) \\
\text { median: } 13.5\end{array}$ \\
\hline DR & 3 & 6 & $76.3(11.2)$ & $68.7(11.9)$ & $\begin{array}{c}103.33(37.43) \\
\text { median: } 88\end{array}$ & $\begin{array}{l}51.17(35.4) \\
\text { median: } 60.5\end{array}$ \\
\hline OHS & 8 & 5 & $74.4(17.2)$ & $71.8(7.3)$ & $\begin{array}{l}96.88(54.78) \\
\text { median: } 71.5\end{array}$ & $\begin{array}{c}77(83.6) \\
\text { median: } 44.5\end{array}$ \\
\hline TD & 19 & 17 & $76.4(8.5)$ & $60.3(22.4)$ & $\begin{array}{c}96.84(53.89) \\
\text { median: } 88\end{array}$ & $\begin{array}{c}54.88(55.23) \\
\text { median: } 35\end{array}$ \\
\hline
\end{tabular}

The sites of the patients' deaths are shown in figure 1 .

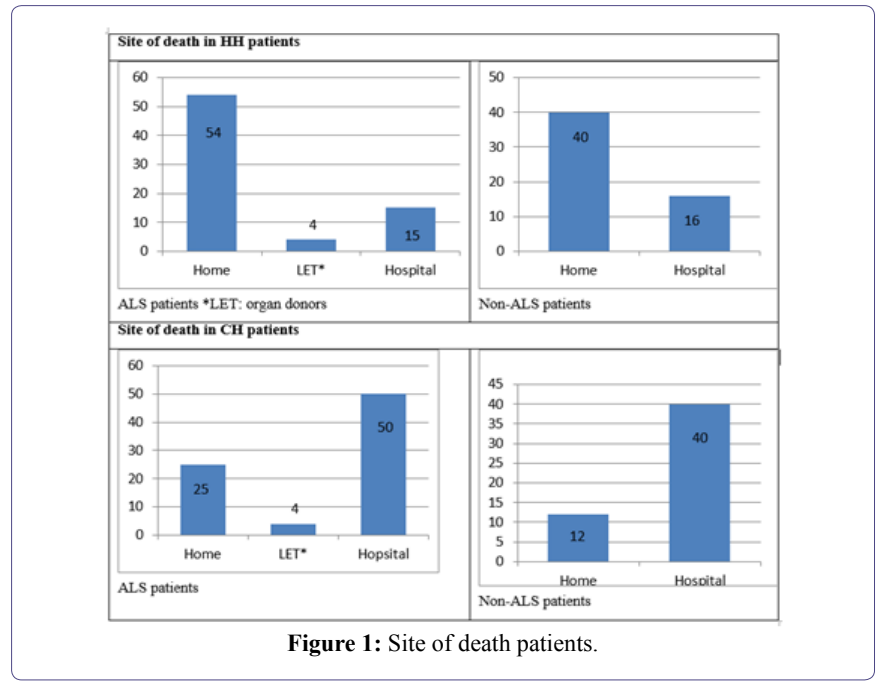

\section{Discussion}

Our access to good infrastructure, appropriate technical equipment and staff with experience in ventilation [2] has enabled us to develop a long-term mechanical ventilation programme conducted entirely through $\mathrm{HH}$, in collaboration with our hospital's Respiratory Medicine Department. This is the first study, to our knowledge, to present data and results covering such a long period.

This is aretrospective cohort study in which the different groups were distributed according to the site of their healthcare, although all the patients were covered by the same regional health service in the same region, with similar socio-economic characteristics. Although significant differences were observed in the initial paO2 of the patients with -non-ELA, none were found in the characteristics of the patients' functional respiratory tests, age or diagnosis. We therefore considered a comparison between the two groups to be valid.

The overall framework of healthcare needs to change in accordance with technological advances and limited access to health resources. A study published by D. Veale on the initiative of the Antadir group[7], describes the various options available in France for introducing ventilation: Conventional hospitalization was most used (by $76 \%$ of prescribers) and outpatient solutions, such as a day hospital or home hospitalization, had a merely anecdotal presence, at $12 \%$ and $6 \%$, respectively. No survey of this kind has been published in Spain but our group is probably the only one to introduce and monitor ventilation in certain patients, and conclude the ventilation with palliative care, all entirely in their home.

Some authors (such as Chatwing, in a randomized study on 28 patients [16]; Lujan [8], with outpatient adaptation to ventilation in 16 patients; and our own group [17], with 42 patients who began NIV at home, have reported similar results with respect to the gaseous exchange and quality of life in patients adapted to ventilation in a hospital setting and those adapted elsewhere. Other publications $[18,19]$ have analyzed the cost of adaptation and follow-up outside the hospital setting and in the home, via Telemedicine, and they found the clinical results to be similar and the costs up to $50 \%$ lower. Homehospitalization follow-up protocols are required, however, and these need to be subsequently evaluated in terms of both clinical results 
Citation: Doménech-Clar R, Compte-Torrero L, Soriano-Melchor E, Ruiz-García V, Valdivieso- Martínínez B, et al. (2020) Home Hospitalization (HH): An Alternative for the Initiation and Control of Mechanical Non-Invasive Ventilation (NIV). J Pulm Med Respir Res 6: 043.

and cost-effectiveness, before it can be concluded more definitely that the adaptation and follow-up of NIV patients in their home not only enhance their healthcare but are also financially efficient.

The training of both patients and carers in operating the respirator and various related aspects [19], along with the quality control of the equipment used [20], is crucial to the success of NIV, so we consider the patients' home to be the ideal place for their follow-up. Several studies have recommended enhancing the care of neuromuscular patients [21] by monitoring certain symptoms [22] in order to implement treatment at an early stage. In our study, we found a low number of hospital admissions for exacerbations in all the diagnoses, possibly due to the ease with which a patient could make immediate telephone contact and receive a response from the $\mathrm{HH}$ unit, allowing for a rapid implementation of treatment and also a lower number of patients who abandon the treatment.

The survival rate of our ALS patients [23] was similar to that of other authors, but significant differences were found when they were compared to ALS patients undergoing conventional hospitalization; we believe that this phenomenon could be linked to the aforementioned possibility of an early implementation of treatment. We did not find any such differences in patients with Duchenne muscular dystrophy, possibly due to their higher survival rate, better technical management by their families and greater independence.

In the case of rapidly progressive neuromuscular diseases in particular, patients must be consulted in good time about their future requirements and desires for the final stages of their life, and their palliative care and preferred site of their death need to be planned, always with the utmost respect for their and their families' social and cultural conditions [24]. We observed a substantial difference between the two groups in our study with respect to palliative care and the site of death. Spain has had considerable experience with palliative care in $\mathrm{HH}$ [25] and a respiratory medicine unit can enable this service to be extended to ventilated patients with the help of good planning.

This study has the limitation of not being randomized. We have confined ourselves to describing the results of our years of experience, without any prior plans for any scientific publication. It would also have been interesting to undertake a cost-effectiveness analysis of our data, but $\mathrm{HH}$ has been shown to be as efficient in this respect as conventional hospitalization [26].

\section{Conclusion}

HH represents a good alternative to conventional hospitalization. Certain groups of ventilated patients followed up in $\mathrm{HH}$ present a better rate of survival and a lower number of hospital admissions, and their palliative care in the final stages of their life is also enhanced.

\section{References}

1. Hannan LM, Dominelli GS, Chen YW, Reid WD, Road J (2014) Systematic review of non-invasive positive pressure ventilation for chronic respiratory failure. Respiratory Medicine 108: 229-243.

2. Domènech R, Nauffal D, Perpiñá M, Compte L, Macián V (2003) Home mechanical ventilation for restrictive thoracic diseases: Effects on patient quality-of-life and hospitalizations. Respiratory Medicine 97: 1320-1327.

3. Rochwerg B, Brochard L, Elliott MW, Hess D, Hill NS, et al. (2017) Official ERS/ATS clinical practice guidelines: Noninvasive ventilation for acute respiratory failure. Eur Respir J 50: 1602426.
4. Wilson ME, Dobler CC, Morrow AS, Beuschel B, Alsawas M, et al. (2020) Association of home noninvasive positive pressure ventilation with clinical outcomes in chronic obstructive pulmonary disease: A systematic review and meta-analysis. JAMA 323: 455-465.

5. Polkey MI, Simonds AK (2017) Homeward bound: A centenary of home mechanical ventilation. American Journal of Respiratory and Critical Care Medicine 195: 1140-1149.

6. Owen SJL, Donaldson GC, Ambrosino N, Escarabill J, Feré R, et al (2005) Patterns of home mechanical ventilation use in Europe: Results from the eurovent survey. Eur Respir J 5: 1025-1031.

7. VealeD, Bermejo JG, Borel JC, Pontier RS, Muir JF, et al. (2010) Mise en route d'une ventilation non invasive: Practiques actuelleset evolution attendues. Enquètes du groupe de travail CasaVNI. Revue des Maladies Respiratoires 27: 1022-1029.

8. LujanM, Moreno A, Veigas C, Martin A, Pomares X, et al. (2007) Non-invasive home mechanical ventilation: Effectiveness and efficiency of an outpatient initiation protocol compared with the standard in-hospital model. Respiratory Medicine 101: 1177-1182.

9. Chatwin M, Hawkins G, Panicchia L, Woods A, Hanak A, et al. (2016) Randomised crossover trial of telemonitoring in chronic respiratory patients (TeleCRAFT trial). Thorax 71: 305-311.

10. Narsavage Gl, Anderson CK, McClure J, Lewarski J, Prentice W, et al. (2005) Statement on home care for patients with respiratory disorders. Am J Respir Crit Care Med171: 1443-1464.

11. Caplan GA, Sulaiman NS, Mangin DA, Ricauda NA, Wilson AD, et al. (2012) A meta-analysis of "hospital in the home". Med J Aust 197: 512519.

12. Conle J, O’Brien CW, Leff BA, Bolen S, Zulman D (2016) Alternative strategies to inpatient hospitalization for acute medical conditions. A Systematic Review. JAMA Intern Med 176: 1693-1702.

13. Jeppesen E, Brurberg KG, Vist GE, Wedzicha JA, Wright JJ, et al. (2012) Hospital at home for acute exacerbations of chronic obstructive pulmonary disease. Cochrane Database Syst Rev 16: 003573.

14. Griffiths C, Foster G, Barnes N, Eldridge S, Tate H, et al. (2004) Specialist nurse intervention to reduce unscheduled asthma care in a deprived multiethnic area: The east London randomised controlled trial for high risk asthma (ELECTRA). BMJ 328: 144-149.

15. BTS guideline (2002) Non-invasive ventilation in acute respiratory failure. Thorax 57: 192-211.

16. Chatwing M, Nickol AH, Morrell MJ, Polkey MI, Smonds AK (2008) Ramdomised trial of inpatient versus outpatient initiation of home mechanical ventilation in patients with nocturnal hypoventilation. Respiratory Medicine 102: 1528-1535.

17. Clar RD, ManssurDN, Torrero LC, Almazán MDR, Pérez EM, et al. (2008) Adaptation and follow-up to noninvasive home mechanical ventilation: Ambulatory versus hospital. Respir Med 102: 1521-1527.

18. Hazenberg A, Kerstjens HAM, Prins SCL, Vermeulen KM, Wijkstra PJ (2014) Initiation of home mechanical ventilation at home: Arandomised controlled trial of efficacy, feasibility and costs. Respir Med 108: 13871395 .

19. Birnkrant DJ, Bushby KMD, Amin RS, Bach JR, Benditt JO, et al. (2010) Therespiratory management of patients with duchenne muscular dystrophy: A DMD care considerations working group specialty article. PediatrPulmonol 45: 1-10.

20. Farre R, Owen SJL, Ambrosino N, Donaldson G, Escarabill J, et al. (2005) Quality control of equipment in home mechanical ventilation: A European survey. Eur Respir J 26: 86-94. 
Citation: Doménech-Clar R, Compte-Torrero L, Soriano-Melchor E, Ruiz-García V, Valdivieso- Martínínez B, et al. (2020) Home Hospitalization (HH): An Alternative for the Initiation and Control of Mechanical Non-Invasive Ventilation (NIV). J Pulm Med Respir Res 6: 043.

- Page 5 of 6 -

21. Peay HL, Meiser B, Kinnett K, Tibben A (2018) Psychosocial needs and facilitators of mothers caring for children with duchenne/becker muscular dystrophy. Duchenne Xchange, USA.

22. Paneronia M, Traininia D, Winckb JC, Vitaccaa M (2014) Pilotstudy for home monitoring of cough capacity in amyotrophic lateral sclerosis: A case series. Revv Prt Neumol 20: 181-187.

23. Khamankar N, Coan G, Weaver B, Mitchell CS (2018) Associative Increases in Amyotrophic Lateral Sclerosis Survival Duration With Non-Invasive Ventilation Initiation and Usage protocols. Front Neurol 9: 578.
24. Andersena PM, Abrahamsb S, Borasioc GD, de Carvalhod M, Chioe A, et al. (2012) EFNS guidelines on the Clinical Management of Amyotrophic Lateral Sclerosis (MALS) - revised report of an EFNS task force. European Journal of Neurology 19: 360-375.

25. Rico CC (2011) Hospitalización a domicilio y cuidados paliativos. MedicinaClinica 137: 43.

26. Caplan GA, Sulaiman NS, Mangin DA, Ricauda NA, Wilson AD, et al. (2012) A meta-analysis of "hospital in the home". Med J Aust 197: 512519. 


\section{If}

Advances In Industrial Biotechnology | ISSN: 2639-5665

Advances In Microbiology Research | ISSN: 2689-694X

Archives Of Surgery And Surgical Education | ISSN: 2689-3126

Archives Of Urology

Archives Of Zoological Studies | ISSN: 2640-7779

Current Trends Medical And Biological Engineering

International Journal Of Case Reports And Therapeutic Studies | ISSN: 2689-310X

Journal Of Addiction \& Addictive Disorders | ISSN: 2578-7276

Journal Of Agronomy \& Agricultural Science | ISSN: 2689-8292

Journal Of AIDS Clinical Research \& STDs | ISSN: 2572-7370

Journal Of Alcoholism Drug Abuse \& Substance Dependence | ISSN: 2572-9594

Journal Of Allergy Disorders \& Therapy | ISSN: 2470-749X

Journal Of Alternative Complementary \& Integrative Medicine | ISSN: 2470-7562

Journal Of Alzheimers \& Neurodegenerative Diseases | ISSN: 2572-9608

Journal Of Anesthesia \& Clinical Care | ISSN: 2378-8879

Journal Of Angiology \& Vascular Surgery | ISSN: 2572-7397

Journal Of Animal Research \& Veterinary Science | ISSN: 2639-3751

Journal Of Aquaculture \& Fisheries | ISSN: 2576-5523

Journal Of Atmospheric \& Earth Sciences | ISSN: 2689-8780

Journal Of Biotech Research \& Biochemistry

Journal Of Brain \& Neuroscience Research

Journal Of Cancer Biology \& Treatment | ISSN: 2470-7546

Journal Of Cardiology Study \& Research | ISSN: 2640-768X

Journal Of Cell Biology \& Cell Metabolism | ISSN: 2381-1943

Journal Of Clinical Dermatology \& Therapy | ISSN: 2378-8771

Journal Of Clinical Immunology \& Immunotherapy | ISSN: 2378-8844

Journal Of Clinical Studies \& Medical Case Reports | ISSN: 2378-8801

Journal Of Community Medicine \& Public Health Care | ISSN: 2381-1978

Journal Of Cytology \& Tissue Biology | ISSN: 2378-9107

Journal Of Dairy Research \& Technology | ISSN: 2688-9315

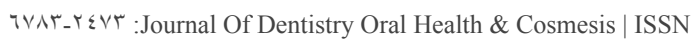

Journal Of Diabetes \& Metabolic Disorders | ISSN: 2381-201X

Journal Of Emergency Medicine Trauma \& Surgical Care | ISSN: 2378-8798

Journal Of Environmental Science Current Research | ISSN: 2643-5020

Journal Of Food Science \& Nutrition | ISSN: 2470-1076

Journal Of Forensic Legal \& Investigative Sciences | ISSN: 2473-733X

Journal Of Gastroenterology \& Hepatology Research | ISSN: 2574-2566
Journal Of Genetics \& Genomic Sciences | ISSN: 2574-2485

Journal Of Gerontology \& Geriatric Medicine | ISSN: 2381-8662

Journal Of Hematology Blood Transfusion \& Disorders | ISSN: 2572-2999

Journal Of Hospice \& Palliative Medical Care

Journal Of Human Endocrinology | ISSN: 2572-9640

Journal Of Infectious \& Non Infectious Diseases | ISSN: 2381-8654

Journal Of Internal Medicine \& Primary Healthcare | ISSN: 2574-2493

Journal Of Light \& Laser Current Trends

Journal Of Medicine Study \& Research | ISSN: 2639-5657

Journal Of Modern Chemical Sciences

Journal of Nanotechnology Nanomedicine \& Nanobiotechnology | ISSN: 2381-2044

Journal Of Neonatology \& Clinical Pediatrics | ISSN: 2378-878X

Journal Of Nephrology \& Renal Therapy | ISSN: 2473-7313

Journal Of Non Invasive Vascular Investigation | ISSN: 2572-7400

Journal Of Nuclear Medicine Radiology \& Radiation Therapy | ISSN: 2572-7419

Journal Of Obesity \& Weight Loss | ISSN: 2473-7372

Journal Of Ophthalmology \& Clinical Research | ISSN: 2378-8887

Journal Of Orthopedic Research \& Physiotherapy | ISSN: 2381-2052

Journal Of Otolaryngology Head \& Neck Surgery | ISSN: 2573-010X

Journal Of Pathology Clinical \& Medical Research

๑ รุ_หษ १: Journal Of Pharmacology Pharmaceutics \& Pharmacovigilance | ISSN

Journal Of Physical Medicine Rehabilitation \& Disabilities | ISSN: 2381-8670

Journal Of Plant Science Current Research | ISSN: 2639-3743

Journal Of Practical \& Professional Nursing | ISSN: 2639-5681

Journal Of Protein Research \& Bioinformatics

Journal Of Psychiatry Depression \& Anxiety | ISSN: 2573-0150

Journal Of Pulmonary Medicine \& Respiratory Research | ISSN: 2573-0177

Journal Of Reproductive Medicine Gynaecology \& Obstetrics | ISSN: 2574-2574

Journal Of Stem Cells Research Development \& Therapy | ISSN: 2381-2060

Journal Of Surgery Current Trends \& Innovations | ISSN: 2578-7284

Journal Of Toxicology Current Research | ISSN: 2639-3735

Journal Of Translational Science And Research

Journal Of Vaccines Research \& Vaccination | ISSN: 2573-0193

Journal Of Virology \& Antivirals

Sports Medicine And Injury Care Journal | ISSN: 2689-8829

Trends In Anatomy \& Physiology | ISSN: 2640-7752

Submit Your Manuscript: http://www.heraldopenaccess.us/Online-Submission.php 